\title{
THE INFLUENCE OF CLIPPING APPLICATION ON YIELD AND SOME YIELD PARAMETERS OF AEGEAN TYPES TOBACCOS
}

\author{
Sidika EKREN*, Emre ILKER \\ Ege University, Faculty of Agriculture, Department of Field Crops, Izmir, TURKEY \\ *Corresponding author: sidika.ekren@ege.edu.tr \\ Received: 02.05.2017
}

\begin{abstract}
The present study was carried out to determine the effects of clipping application on seedling and field performance of three tobacco varieties in 2014 and 2015. Akhisar-97, Izmir-Ozbas and Saribaglar-407 tobacco varieties were planted based on randomized complete block design with three replications. In the research, the effects of clipping application on lenght of the seedling, stem diameter, healthy seedlings per square, plant height, number of the leaves, leaf width, leaf lenght and cured leaf yield were evaluated. Average results of two years indicated that clipping application on lenght of seedling, stem diameter, plant height, leaf width, leaf lenght and cured leaf yield were higher than traditional method. Akhisar-97 had statistically high performance than the Izmir-Ozbas and Saribaglar-407 tobacco varieties. The highest lenght of the seedling was obtained in Akhisar-97 $(21.0 \mathrm{~cm})$ tobacco cultivar by using clipping application for both years. Cured leaf yield results indicated that Akhisar-97 tobacco variety was the highest yield as $1037 \mathrm{~kg} \mathrm{ha}^{-1}$ at clipping application whereas the lowest yield was recorded as $717 \mathrm{~kg} \mathrm{ha}^{-1}$ in traditional practice in the second year.
\end{abstract}

Key words: Aegean tobacco, clipping, seedling, yield

\section{INTRODUCTION}

Turkey is the biggest producer of aromatic oriental tobacco which is one of the major traditional crops. This plant is compatible for growing on soil conditions, not suitable or profitable for growing other types of agricultural products. It is often grown in poorer soils and in areas with higher aridity. Turkey has favorable soil and climatic conditions and tradition for growing mostly small-leaf oriental or aromatic types of tobacco and very small quantities of big leaf types of tobaccos. The harvested leaves are mostly sun-cured and the characteristic golden-yellow leaf is widely famous for its quality chracteristics oriental tobaccos are known by their high aroma from the small leaves, being low in nicotine. Most of the world largest cigarette makers use this tobacco to enrich the aroma and quality of their cigarettes (Gumus Guler, 2008). This tobacco is also paramount importance to the agriculture sector and the economy of Turkey as it is one of the country biggest foreign currency earners (Anonymous, 2015).

Tobacco production in Turkey has been decreasing sharply in the recent years. Just like tobacco production, tobacco yield also followed decreasing. There are many factors causing the decline in production. Some of them are reduction in the number of families producing tobacco, 45 years and older consists of farmers, price policy, antismoking policy and the challenges of the agricultural practices. As well as, to grow tobacco in the same field every year and to use of low seed purity is among the main factors in the decrease of the yield. So, decreasing the tobacco production is the most important problems in terms of sustainability of the production (Celen et al., 2016).

The first stage in the production of a good quality and high-yielding crop begins in the seedbed. Good seedbed management is required in the seedbed period in order to obtain healty uniform seedlings with well-developed root and stem (Anonymous, 2012).

In the seedling stage, the average daily temperature and sunlight hours are major factors affecting the seedling age and quality (Jin et al., 2014). The clipping application, defined by Miner (1978) as removal of that portion of the plant's leaf tissue that can be raised above the apical meristem. This practice was first use in Zimbabwe to harden tobacco transplant (Kille, 1970). It is now practiced in a majority of tobacco producing countries around the world to create healthier, stronger seedlings and root systems. In this application, seedlings are cut at a height of $2.5 \mathrm{~cm}$ above the point at which the leaf joins the stem, at specific time intervals, in order to obtain healthier and homogeneous seedlings. (Anonymous, 2012). Furthermore, clipped plants are more uniform have a higher percentage of usability are hardier and are easier to mechanically transplant (Fisher et al., 2002). 
In the light of these informations obtained by previous studies, to produce high quality tobacco, growers must begin with healthy seedlings. The ideal seedling is disease free, hardy enough to survive transplanting shock and available for transplanting in time. In general, earlier transplanted seedlings give better yield than late transplanted tobacco (Smith et al., 2003). The overlong growth period of tobacco seedlings and low temperature conditions is a major problem. The long growth period of seedlings will lead to less effective leaves, poor stress resistance and low economic benefit of tobacco production (Zhu and Sun, 2007). Light, temperature, water, fertilizer and other environmental factors are key factors of tobacco seedlings growth (Liu et al., 2003). Good tobacco seedlings lead to excellent tobacco leaf quality and high economic benefit.

For successful production and obtaining uniformity according to the morphological and biological characteristics of tobacco at yield, the quality of tobacco seedlings must be good (Kabranova et al., 2014). Agroecological conditions have strong influence on its biological, morphological and technological characteristics. Production of tobacco seedling has important role as regular measure of the tobacco production technology (Uzunovski, 1989).
Traditionally seedlings in Turkey, especially oriental type of tobacco, are produced at open field, in cold beds, covered with polyethylene. During the seedbed period, seedbed management is done by the tobacco growers such as irrigation, ventilation and weeding etc. But in the last years, clipping application have been used by the agronomist who work in tobacco factory to growers in our country.

To our knowledge, no similar study has been undertaken in Turkish oriental tobacco at the seedbed and field conditions. The primary objective of this study was to evaluate the influence of clipping application on the yield and some yield components of oriental tobacco. A secondary aim of the present research was to compared differences among the tobacco types at the seedbed and field period.

\section{MATERIAL AND METHODS}

\section{Location of experiment}

The experiment was carried out for two years in 2014 and 2015 in the research fields of the Ege University, Faculty of Agriculture, Department of Field Crops. The soil texture for the field experimental plots is clayey-loam. Some physical and chemical characteristics of the soil are shown in Table 1.

Table 1. Some soil physical and chemical characteristics at the experimental plot.

\begin{tabular}{l|c|l|l|l|l|l|l|l|c}
\hline $\begin{array}{l}\text { Depth } \\
(\mathbf{c m})\end{array}$ & $\mathbf{p H}$ & $\begin{array}{l}\text { Total } \\
\text { Soluable } \\
\text { Salt } \mathbf{( \% )}\end{array}$ & $\begin{array}{l}\mathbf{C a C O}_{3} \\
\mathbf{\%}\end{array}$ & $\begin{array}{l}\text { Organik } \\
\text { matter } \\
(\boldsymbol{\%})\end{array}$ & $\begin{array}{l}\text { Total N } \\
(\boldsymbol{\%})\end{array}$ & $\begin{array}{l}\text { Sand } \\
(\boldsymbol{\%})\end{array}$ & $\begin{array}{l}\text { Silt } \\
(\boldsymbol{\%})\end{array}$ & $\begin{array}{l}\text { Clay } \\
(\boldsymbol{\%})\end{array}$ & Texture \\
\hline $0-30$ & 7.61 & 0.074 & 23.98 & 2.82 & 0.129 & 28.60 & 39.40 & 32.00 & Clayey loam \\
$30-60$ & 7.64 & 0.080 & 24.65 & 2.72 & 0.101 & 31.00 & 38.60 & 30.40 & Clayey loam \\
\hline
\end{tabular}

Experimental area is $20 \mathrm{~m}$ above sea level with mild total precipitation are presented in Table 2 for the two Mediterranean climate type. Average temperature and years and long term period.

Table 2. Monthly average temperature and precipitation in Bornova

\begin{tabular}{|c|c|c|c|c|c|c|}
\hline & \multicolumn{3}{|c|}{ Average Temperature $\left({ }^{\circ} \mathrm{C}\right)$} & \multicolumn{3}{|c|}{ Total precipitation (mm) } \\
\hline & 2014 & 2015 & LYA & 2014 & 2015 & LYA \\
\hline January & 9.9 & 8.9 & 9.0 & 113.8 & 125.1 & 112.2 \\
\hline February & 9.7 & 9.5 & 9.2 & 45.6 & 101.9 & 99.7 \\
\hline March & 11.5 & 11.7 & 11.8 & 108.4 & 75.6 & 82.9 \\
\hline April & 15.0 & 15.9 & 16.1 & 76.8 & 46.4 & 46.4 \\
\hline May & 19.3 & 20.8 & 21.0 & 2.2 & 30.9 & 25.4 \\
\hline June & 23.8 & 25.6 & 26.0 & 75.2 & 9.8 & 7.5 \\
\hline July & 26.8 & 28.0 & 28.3 & 16.0 & 1.8 & 2.1 \\
\hline August & 28.3 & 27.7 & 27.9 & 6.0 & 2.6 & 1.7 \\
\hline September & 23.0 & 23.7 & 23.9 & 18.6 & 15.0 & 19.9 \\
\hline October & 18.8 & 18.8 & 19.1 & 49.0 & 45.3 & 43.2 \\
\hline November & 13.2 & 14.0 & 13.8 & 15.2 & 94.8 & 109.7 \\
\hline December & 11.1 & 10.6 & 10.5 & 206.8 & 141.1 & 137.9 \\
\hline$X-\Sigma$ & 17.5 & 17.9 & 18.1 & 753.6 & 690.3 & 688.6 \\
\hline
\end{tabular}

LYA: long year average $\mathrm{X}$ : mean $\quad \Sigma$ : total (Anonymous, 2016) 


\section{Seedbed management}

Nicotiana tabacum L. cv Akhisar-97, Izmir-Ozbas and Sarıbaglar 6267 were used as the research material in this study. These registered tobacco cultivars are mostly used in Aegean Region tobacco farmers and prefered by the tobacco industry and trade companies. The seeds with ash mixture were sown $\left(0.6 \mathrm{~g} \mathrm{~m}^{-2}\right)$ at the begining of March in 2014 and 2015 (Table 3) into a mixture of sand, manure, mulch (1:1:1). Following this, well fermented manure covering was placed, spread and leveled to $1 \mathrm{~cm}$ on top of the seedbed by compressing it. Then, seedbed was irrigated and covered with a plastic cover. During the seedbed management, some cultural practices such as irrigation, weed control and ventilation were performed regularly. Seedlings were clipped twice throughout the seedbed period. When the tobacco seedlings were reached $5 \mathrm{~cm}$ height first clipping was done. Second was applied one week later after the first clipping. At the clipping treatments, seedlings were cut at the height of $2.5 \mathrm{~cm}$ above the point.

Table 3. Seedling, setting and harvesting dates

\begin{tabular}{l|l|l}
\hline & $\mathbf{2 0 1 4}$ season & 2015 seasson \\
\hline Seedbed & $5^{\text {th }}$ March & $9^{\text {th }}$ March \\
First clipping & $9^{\text {th }}$ April & $7^{\text {th }}$ April \\
Second clipping & $16^{\text {th }}$ April & $15^{\text {th }}$ April \\
Counts determined in seedbed & $12^{\text {th }}$ May & $14^{\text {th }}$ May \\
Set & $22^{\text {th }}$ May & $20^{\text {th }}$ May \\
Counts determined in field & $21^{\text {st } J u n e ~}$ & $24^{\text {th }}$ June \\
Harvest $1^{\text {st }}$ & $30^{\text {th } J u n e}$ & $26^{\text {th }}$ June \\
Harvest $2^{\text {nd }}$ & $25^{\text {th }}$ July & $31^{\text {st }}$ July \\
Harvest $3^{\text {rd }}$ & $18^{\text {th }}$ August & $14^{\text {th }}$ August \\
\hline
\end{tabular}

\section{Field period and experimental design}

Experimental plot was ploughed deeply in autumn. Before the planting in the spring, the field was ploughed and harrowed shallowly. The field experiment was carried out according to randomized completely block design (RCBD) with three replications. Each plot consisted of three rows with $3 \mathrm{~m}$ lenght and $40 \times 10 \mathrm{~cm}$ of plant spacing in traditional (non-clipping) and clipping application. Seedlings were transplanted to the experimental plot by hand. When the seedlings reached $15-20 \mathrm{~cm}$ plant height, they were transferred to the experimental plots in midMay in both years. After the planting, the seedlings were irrigated with lifeline-water whereas there was no irrigation and hoeing was done twice in the vegetation period. Fertilization was not applied before and after planting. The leaves were harvested by hand when the tobacco leaves reached maturing stage. Harvesting done $1^{\text {st }}, 2^{\text {nd }}$ and $3^{\text {rd }}$ stalk position hand and cured (Table 3 ).

\section{Measurement at seedbed and field period}

Observations at the seedbed period were made on the following traits:

Lenght of the seedling $(\mathrm{cm})$ : The seedling was measured from the bottom to the top level of the seedling before the transplanting

Stem diameter $(\mathrm{mm})$ : The seedling diameter was measured at the middle of the seedling

Healthy seedlings per square $\left(\mathrm{pcs} / \mathrm{m}^{2}\right)$ : The frame (seedling counting scale) is placed in a section of the seedbed. All seedlings within the inside borders of the frame are counted.
During the field period, after the side effects were eliminated, the remaining plants in each plot were used for the measurements set out below:

Plant height $(\mathrm{cm})$ : The plants were measured from the ground level to the point at which the inflorescence was removed

Number of leaves (per/plant): The number of harvested leaves were counted per plant

Leaf Length $(\mathrm{cm})$ : Leaf length was measured from the leaf top to the leaf base

Leaf Width $(\mathrm{cm})$ : The leaf was measured from edge to edge at the widest part of the leaf lamina

Cured leaf yield $\left(\mathrm{kg} \mathrm{ha}^{-1}\right)$ : The plants were harvested by hand according to the stalk position. Then the plot yield was converted to yield for a hectare

All measurements were performed by using the methods proposed by Anonymous, 2004.

\section{Statistical analysis}

Data from the experiment were subjected to analysis of variance (ANOVA) using TOTEM STAT statistical software (Acikgoz et al., 2004). The mean differences were compared by the least significant difference (LSD) test (Steel et al., 1997).

\section{RESULTS AND DISCUSSION}

\section{Seedbed period}

Lenght of the seedling

Significant differences were found among the genotypes for seedling length in both years. The highest lenght of the seedling was found in Akhisar-97 as $20.3 \mathrm{~cm}$ in 2014 and $20.2 \mathrm{~cm}$ in 2015 whereas the lowest lenght of 
the seedling was obtained in Sarıbaglar as $18.2 \mathrm{~cm}$ in the first year and $18.5 \mathrm{~cm}$ in the second year (Table 4). The results indicated that clipping application was found statistically significant on lenght of the seedling in 2015 but not in 2014 .

Table 4. Mean values at seedbed period for both cultivars and the applications

Lenght of the seedling (cm)

Cultivars

2014

2015

\begin{tabular}{lllllll} 
& Traditional & Clipping & Mean & Traditional & Clipping & Mean \\
\hline Akhisar -97 & 19.7 & 21.0 & $20.3^{\mathrm{a}}$ & 19.3 & 21.0 & $20.2^{\mathrm{a}}$ \\
Izmir-Ozbas & 18.3 & 19.3 & $18.8^{\mathrm{b}}$ & 18.7 & 19.0 & $18.8^{\mathrm{b}}$ \\
Saribaglar-407 & 17.7 & 18.7 & $18.2^{\mathrm{b}}$ & 17.7 & 19.3 & $18.5^{\mathrm{b}}$ \\
\hline Mean & 18.6 & 19.7 & 19.1 & $18.6^{\mathrm{b}}$ & $19.8^{\mathrm{a}}$ & 19.2 \\
\hline \multicolumn{2}{c}{ LSDcul: $1.46^{* *}$} & & \multicolumn{2}{c}{ LSDcul: $1.24 * *$} & LSDapp: $1.01^{* *}$ \\
\hline CV $(\%)$ & 5.94 & & 5.04 & \\
\hline
\end{tabular}

Stem diameter $(\mathrm{cm})$

Cultivars

2014

2015

\begin{tabular}{lllllll} 
& Traditional & Clipping & Mean & Traditional & Clipping & Mean \\
\hline Akhisar -97 & $0.35^{\mathrm{a}}$ & $0.41^{\mathrm{a}}$ & 0.38 & 0.38 & 0.43 & $0.41^{\mathrm{a}}$ \\
Izmir-Ozbas & $0.37^{\mathrm{a}}$ & $0.37^{\mathrm{b}}$ & 0.37 & 0.34 & 0.36 & $0.35^{\mathrm{b}}$ \\
Saribaglar-407 & $0.29^{\mathrm{b}}$ & $0.34^{\mathrm{b}}$ & 0.31 & 0.25 & 0.28 & $0.27^{\mathrm{c}}$ \\
\hline Mean & 0.33 & 0.37 & 0.35 & $0.32^{\mathrm{b}}$ & $0.36^{\mathrm{a}}$ & 0.34 \\
\hline \multicolumn{2}{c}{ LSDculxapp: $0.03^{* *}$} & & LSDcul: $0.033^{*}$, & LSDapp:0.027** \\
\hline CV $(\%)$ & 4.74 & & & \\
\hline
\end{tabular}

Cultivars

2014

2015

\begin{tabular}{|c|c|c|c|c|c|c|}
\hline & Traditional & Clipping & Mean & Traditional & Clipping & Mean \\
\hline Akhisar -97 & 24.7 & 21.3 & $23.0^{\mathrm{a}}$ & 23.3 & 21.0 & $22.2^{\mathrm{a}}$ \\
\hline Izmir-Ozbas & 20.3 & 18.0 & $19.2^{\mathrm{b}}$ & 21.0 & 18.7 & $19.8^{b}$ \\
\hline Saribaglar-407 & 19.3 & 17.3 & $18.3^{\mathrm{b}}$ & 20.0 & 18.7 & $19.3^{\mathrm{b}}$ \\
\hline \multirow[t]{2}{*}{ Mean } & $21.4^{\mathrm{a}}$ & $18.9^{\mathrm{b}}$ & 20.2 & $21.4^{\mathrm{a}}$ & $19.4^{\mathrm{b}}$ & 20.4 \\
\hline & LSDcul: $0.85^{*}$ & LSDapp:0.69* & & \multicolumn{2}{|c|}{ LSDcul: $1.09^{*}$} & pp: $0.89 *$ \\
\hline $\mathrm{CV}(\%)$ & \multicolumn{3}{|c|}{3.26} & \multicolumn{3}{|c|}{4.16} \\
\hline
\end{tabular}

$* \mathrm{p}<0.05, * * \mathrm{p}<0.01$, ns: not significant

Lenght of the seedling mostly depends on living space for development of the plant, number of the plants per $\mathrm{m}^{2}$, agro-technological measures as well as technology of seedlings production (Pearce et al., 2005). Kabranova et al. (2014) indicates that the lenght of stem is appropriate as well as number of leaves and if phosphate level kept lower, top and root growth present a better balance. In other studies, lenght of the seedling was found to be change from $6 \mathrm{~cm}$ to $21 \mathrm{~cm}$ (Turi et al., 2004; Ayan and Caliskan, 2006; Hou-Long et al., 2014). The results were consistent with these scientists.

\section{Stem diameter}

Stem diameter was affected by methods $\mathrm{x}$ variety interaction. It was determined between $0.29-0.41 \mathrm{~mm}$ and the highest stem diameter was obtained in Aksihar-97 tobacco variety at clipping practice in the first year of experiment. For the second year, stem diameter was significantly affected by both the tobacco cultivars and application methods. As seen from the average results, the highest results were determined in Akhisar-97 as $0.41 \mathrm{~mm}$ 
and being in Izmir-Ozbas as $0.35 \mathrm{~mm}$ at clipping, respectively.

According to the Kabranova et al. (2014) great stem diameter is a great potential for further plant development. Stem diameter was obtained between $4.1 \mathrm{~mm}$ and $5.7 \mathrm{~mm}$ in Prilep NS72 and Yaka 125/3 tobacco varieties. Turi et al. (2004) was found that stem diameter changed from 2.6 $\mathrm{mm}$ to $4.1 \mathrm{~mm}$. Our results were lower than these scientists because the stem diameter has been affected by the tobacco variety which was used.

\section{Healthy seedlings per square}

In our study, there were statistically significant differences for healty seedling per square area in terms of tobocco cultivars and applications in two years. The average results among the cultivars were changed between 18.3-23.0 pcs and healthy seedling per square at traditional practice ( $21.4 \mathrm{pcs})$ was higher than clipping treatment (18.9 pcs) in 2014. There is a similar results were obtained in the second year of the study. Clipping application (19.4 pcs) was lower than traditional method (21.4 pcs). The highest healthy seedling per square was recorded in Akhisar-97 as 22.2 pcs. To the author's knowledge, there is no previous study about healthy seedling per square at seedbed period of Aegean tobaccos.

\section{Field period}

Plant height

It was understood that the two different practise applied did not have any significant effect on plant height in both years. The average plant height in clipping application $(76.0 \mathrm{~cm})$ was higher than in traditional $(72.8$ $\mathrm{cm})$. However, when we look at the mean values of the varieties in 2014, it is determined that the Akhisar is significantly higher than the other two varieties besides, this situation is maintained in 2015 as well. The values of plant height ranged from $70.7 \mathrm{~cm}$ to $78.7 \mathrm{~cm}$ depending on methods and average plant height was determined 74.2 cm (Table 5).

Table 5. Mean values of plant height for both cultivars and the applications (cm)

Cultivars

2014

2015

\begin{tabular}{lllllll} 
& Traditional & Clipping & Mean & Traditional & Clipping & Mean \\
\hline Akhisar -97 & 75.7 & 81.7 & $78.7^{\mathrm{a}}$ & 76.7 & 78.7 & 77.7 \\
Izmir-Ozbas & 72.0 & 74.3 & $73.2^{\mathrm{b}}$ & 70.7 & 72.0 & 71.3 \\
Saribaglar-407 & 70.7 & 72.0 & $71.3^{\mathrm{b}}$ & 73.3 & 74.0 & 73.7 \\
\hline Mean & 72.8 & 76.0 & 74.4 & 73.6 & 74.9 & 74.2 \\
\hline \multicolumn{2}{c}{ LSDcul: $4.96^{* *}$} \\
\hline $\mathrm{pV}(\%)$
\end{tabular}

Tobacco types and cultivars differed significantly in their growth rates and patterns after 60 days from transplanting. Cultivars within the same type were not significantly different. All of the measured growth characteristics followed the sigmoid growth curve with the period of rapid growth being from 30-60 days after transplanting. Aromatic or oriental cultivars were fast growing, early maturing and low in total dry matter (Tso, 1990). The differences in the plant height of Izmir type tobacco cultivars among the three years can be explained by the changes in the genotypes. The average plant height were determined between 53 and $63 \mathrm{~cm}$ reported by Kucukozden et al., (2002). Peksuslu et al. (2002) also studied 8 Izmir type tobacco genotypes at 6 location for two years, mean plant height was found as $62.1 \mathrm{~cm}$. The plant height of Aegean tobaccos ranged from 40 to 100 $\mathrm{cm}$ depending on the genotypes (Ekren, 2007; Camas et al., 2009a; Cabadan et al., 2014; Harputlu et al., 2014; Kinay, 2014; Celen et al., 2016). In our study, the plant height are found to be higher than Kucukozden et al.
(2002) and Peksuslu et al. (2002) but similar to other scientific studies.

\section{Number of the leaf ( per/plant)}

As seen in Table 6, there was no statistically significant differences among the varieties and both applications for two years. The values of the first year, the highest average number of the leaf was obtained from Akhisar-97 and Izmir-Ozbas varieties being 27.8 per/plant whereas the lowest number of the leaf was found in Sarıbaglar being 27.0 per/plant. Number of the leaf at traditional and clipping practice was to similar results being as 27.6 per/plant.

In the study second year average results was shown that number of the leaf in Akhisar-97 (28.0 per/plant) was higher than the Izmir-Ozbas (27.0 per/plant) the lowest number of the leaf was obatained in Izmir-Ozbas (26.5 per/plant) tobacco cultivar. Number of the leaf at clipping (27.5 per/plant) was higher than traditional practice $(26.8$ per/plant). 
Table 6. Mean values of number of the leaf for both cultivars and the applications (per/plant)

Cultivars

2014

2015

\begin{tabular}{lllllll} 
& Traditional & Clipping & Mean & Traditional & Clipping & Mean \\
\hline Akhisar -97 & 27.7 & 28.0 & 27.8 & 27.7 & 28.3 & 28.0 \\
Izmir-Ozbas & 27.7 & 28.0 & 27.8 & 26.7 & 27.3 & 27.0 \\
Saribaglar-407 & 27.3 & 26.7 & 27.0 & 26.0 & 27.0 & 26.5 \\
\hline Mean & 27.6 & 27.6 & 27.5 & 26.8 & 27.5 & 27.2 \\
\hline CV $(\%)$ & 7.94 & & & 7.57 & \\
\hline
\end{tabular}

${ }^{*} \mathrm{p}<0.05, * * \mathrm{p}<0.01$, ns: not significant

Number of the leaf is related with crop quality. Leaf number ranged from 23 to 35 per/plant in local genotypes of Aegean Region. Some researchers stated that leaf number affected by genotypes, enviromental conditions and cultivation applications ranged from 17 to 50 per/plant (Otan and Apti, 1989; Gencer, 2001; Ekren, 2007; Camas et al., 2009b; Koseoglu et al., 2014). Number of the leaf which is determined increased or decreased of yield was found between 23-35 per/plant at local cultivar and was obtained from 35 to $50 \mathrm{per} / \mathrm{plant}$ at registered variety (Anonymous, 2002). Our results showed a similarity to the results given by other scientist.

\section{Leaf width and leaf lenght $(\mathrm{cm})$}

The values for leaf width and leaf lenght are presented in Table 7. According to the first year results, cultivar effect was statistically significant on leaf width, average value of Akhisar-97 $(6.4 \mathrm{~cm})$ was higher than Saribaglar $(5.7 \mathrm{~cm})$. The lowest leaf width was obtained from IzmirOzbas tobacco variety. Leaf width increased by clipping practice $(6.0 \mathrm{~cm})$ but decreased in traditional $(5.7 \mathrm{~cm})$. In the second year, applied two different applications have significantly effect on leaf width. The average leaf width of the varieties ranged from $5.3 \mathrm{~cm}$ to $6.5 \mathrm{~cm}$. among the cultivars. Mean values of applying practise was similar to first year results. Traditional practice $(5.8 \mathrm{~cm})$ was lower than clipping $(5.9 \mathrm{~cm})$.

Table 7. Mean values of leaf width and leaf lenght for both cultivars and the applications

\section{Leaf width $(\mathrm{cm})$}

Cultivars

2014

2015

\begin{tabular}{|c|c|c|c|c|c|c|}
\hline & Traditional & Clipping & Mean & Traditional & Clipping & Mean \\
\hline Akhisar -97 & 6.2 & 6.5 & $6.4^{\mathrm{a}}$ & 6.5 & 6.6 & $6.5^{\mathrm{a}}$ \\
\hline Izmir-Ozbas & 5.3 & 5.5 & $5.4^{\mathrm{b}}$ & 5.6 & 5.8 & $5.7^{\mathrm{b}}$ \\
\hline Saribaglar-407 & 5.6 & 5.9 & $5.7^{\mathrm{b}}$ & 5.2 & 5.4 & $5.3^{\mathrm{c}}$ \\
\hline Mean & 5.7 & 6,0 & 5.8 & 5.8 & 5.9 & 5.8 \\
\hline \multicolumn{4}{|c|}{ LSDcul: $0.326^{* *}$} & \multicolumn{3}{|c|}{ LSDcul:0.316** } \\
\hline $\mathrm{CV}(\%)$ & \multicolumn{3}{|c|}{4.34} & \multicolumn{3}{|c|}{4.2} \\
\hline
\end{tabular}

Cultivars

2014

2015

\begin{tabular}{lllllll} 
& Traditional & Clipping & Mean & Traditional & Clipping & Mean \\
\hline Akhisar -97 & 12.9 & 13.5 & $13.2^{\mathrm{a}}$ & 13.1 & 13.5 & $13.3^{\mathrm{a}}$ \\
Izmir-Ozbas & 11.3 & 11.7 & $11.5^{\mathrm{b}}$ & 11.6 & 12.0 & $11.8^{\mathrm{b}}$ \\
Saribaglar-407 & 11.7 & 12.4 & $12.1^{\mathrm{b}}$ & 10.7 & 11.0 & $10.9^{\mathrm{c}}$ \\
\hline Mean & $11.9^{\mathrm{b}}$ & $12.5^{\mathrm{a}}$ & 12.3 & 11.8 & 12.2 & 12.0 \\
\hline \multicolumn{3}{c}{ LSDcul: $0.516^{* *}$ LSDapp:0.632** } \\
\hline CV $(\%)$
\end{tabular}


The finding indicated that applications and cultivars were found statistically significant on leaf lenght in 2014. Considering the varieties, leaf lenght was changed between 11.5 and $13.2 \mathrm{~cm}$. Leaf lenght in Akhisar-97 cultivar was higher than others and this is similar to the leaf width. The average leaf lenght was found for $11.9 \mathrm{~cm}$ in traditional and $12.5 \mathrm{~cm}$ in clipping application in 2014 The results of the second year was presented in Table 6 . Cultivar leaf lenght was ranged from $10.9 \mathrm{~cm}$ to $13.3 \mathrm{~cm}$. Leaf lenght was increased with the clipping application $(12.2 \mathrm{~cm})$. Average leaf lenght was determined as $12.0 \mathrm{~cm}$ in 2015 .

Leaf width and lenght is one of the most important quality criteria for Aegean tobaccos to determine the visual quality and market price of tobacco and characterized by their small leaves. The tobaccos have defined small and medium leaf size, slightly dense density by the Turkish Standart Organization (TSE) (Anonymous, 2004). Leaf lenght would be two or three times the width and large leaves are very poor quality. With little aroma and generally considered unsuitable for use as oriental tobaccos (Akehurst, 1970). In the Aegean tobaccos leaf width was determined between 5 and $8 \mathrm{~cm}$; leaf lenght was ranged from 5 to $17 \mathrm{~cm}$ (Suben, 1976; Kucukozden et al., 2002; Peksuslu, et al., 2002; Camas et al., 2007; Celen et al., 2016). Our findings are in accordance with those researcher's results.

\section{Crude Leaf Yield $\left(\mathrm{kg} \mathrm{ha}^{-1}\right)$}

Although cultivar $\mathrm{x}$ application interaction at first year results were significant in terms of cured leaf yield, LSD ranking of the cultivars two different practices did not changed. In addition, because of the fact that the yield performance of Izmir-Ozbas tobacco cultivar at traditional and clipping application in 2014 were not change vice versa, yield results of other two types of tobacco variety was considerably increased, interaction has become important.

According to the second year results, when we compared to the application performances, cured leaf yield was increased noticeably by using, clipping practices. Considering the both application average, the highest yield was obtained from Akhisar variety $(997 \mathrm{~kg}$ $\left.\mathrm{ha}^{-1}\right)$ whereas Saribaglar $\left(750 \mathrm{~kg} \mathrm{ha}^{-1}\right)$ was the lowest in 2015 (Table 8).

Table 8. Mean values of cured leaf yield for both cultivars and the applications ( $\left.\mathrm{kg} \mathrm{ha}^{-1}\right)$

Cultivars

2014

2015

\begin{tabular}{lllllll} 
& Traditional & Clipping & Mean & Traditional & Clipping & Mean \\
\hline Akhisar -97 & $930^{\mathrm{a}}$ & $1000^{\mathrm{a}}$ & 965 & 957 & 1037 & $997^{\mathrm{a}}$ \\
Izmir-Ozbas & $850^{\mathrm{b}}$ & $850^{\mathrm{b}}$ & 850 & 800 & 860 & $830^{\mathrm{b}}$ \\
Saribaglar-407 & $800^{\mathrm{c}}$ & $780^{\mathrm{c}}$ & 790 & 717 & 783 & $750^{\mathrm{c}}$ \\
\hline Mean & $860^{\mathrm{b}}$ & $877^{\mathrm{a}}$ & 868 & $825^{\mathrm{b}}$ & $893^{\mathrm{a}}$ & 859 \\
\hline \multicolumn{2}{c}{ LSDapp:15.93** } & \multicolumn{4}{c}{ LSDcul:4.765** LSDapp:38.91** } \\
\hline CV $(\%)$ & 1.01 & & \multicolumn{4}{c}{4.31} \\
\hline${ }^{*}<0.05, * * \mathrm{p}<0.01$, ns: not significant & &
\end{tabular}

Morphological development of tobacco plants greatly affects the physical and chemical characteristics of tobacco leaf and thus its quality, usability and yield. Besides, there are a lot of factors effects on the tobacco yield such as environmental conditions, soil type, application practice. Shyu et al. (1975) and Peksuslu et al. (2002) indicates that yield is a complex character and greatly affected by environmental factors and tobacco cultivars. In tobacco production, yield and quality are the most important features of it. The quality of leaf is directly related with its compositon (Kurt and Ayan, 2014). Curing time and curing methods also effects on the tobacco yield when the curing time has increased, dry matter decreased reported by some researches (Sekin, 1986; Reddy and Sreeramanurthy, 1993; Yazan et al., 1993). Ekren et al. (2015) found that the tobacco yields were 1560 and $3130 \mathrm{~kg} \mathrm{ha}^{-1}$ in traditional and double cross planting methods, respectively. Many researchers stated that mean yield of Aegean tobaccos ranged from 800 to
2500 kg ha-1 (Er, 1994; Uz, 1997; Ekren, 2007; Cabadan et al., 2014; Koseoglu et al., 2014). Similar results of cured leaf yield were reported by Er (1994), Uz (1997) and Ekren (2007). However, our datas were lower than Cabadan et al. (2014), Koseoglu et al. (2014) and Ekren et al. (2015). These research results revealed that applying different planting method and fertilizer were increased the cured leaf yield.

\section{CONCLUSION}

It can be said that there is a significant decrease in the Aegean Region in parallel with the total tobacco production of Turkey in the recent years. It is important to determine the increase of the some parameters on yield for oriental tobaccos when the tobacco production threat decreases. It should be emphasized that clipping application carried out on Aegean tobaccos that it is a positive effect on yield and yield parameters and therefore clipping should be a recommended practice. In this study 
were as follows: lenght of seedlings $18.6-19.8 \mathrm{~cm}$; stem diameter $0.32-0.37 \mathrm{~cm}$; healthy seedling per square 18.9 21.4 pcs; plant height $72.8-76.0 \mathrm{~cm}$; number of the leaves 26.8-27.6 per/plant; leaf width 5.7-6.0 cm; leaf lenght 11.8-12.5 cm; cured leaf yield $825-893 \mathrm{~kg} \mathrm{ha}^{-1}$. The results of Aegean tobaccos were in accordance with the data given in the previous studies and they are within the limits rate. Future experiments on clipping application should be conducted at different provinces with various agronomical treatments.

\section{ACKNOWLEDGMENTS}

We thank to the Ege University Directorate of Scientific Research Project for its financial support to this study (Project Number: 2014-ZRF-023).

\section{LITERATURE CITED}

Acikgoz, N., E. Ilker and A. Gokcol. 2004. Assessment of Biological Research on the Computer. ISBN: 973-483-607-8 Ege University Seed Technology Center, Publication No: 2 Bornova-Izmir, Turkey (in Turkish).

Akehurst. B. C. 1970. Tobacco. Lowe and Brydone Ltd. London. Anonymous. 2002. Turkish Tobaccos. Dimon Turkish Tobacco Company. First Edition.

Anonymous. 2004. TSE 1000 Turkish Tobaccos Standard, Ankara (in Turkish).

Anonymous. 2012. Izmir oriental tobacco agronomy guideline. Aegean Exporters'Associations. First Edition.

Anonymous. 2015. Food and Agriculture Organization of the United Nations. Available from www.fao.org Access date: 15.01.2017

Anonymous. 2016. Bornova Meteorological Data of Olive Research Institute, Izmir.

Ayan, A.K. and O. Caliskan. 2006. Seedling quality of fluecured tobaccos as affected by different types of peat. Communications in Biometry and Crop science. Vol. 1, No. 1, pp. 56-62.

Celen, A.E., S. Ekren, V. Koparan and E. Ilker. 2016. The effects of different planting methods on tobacco quality yield and yield parameters. "Coresta Congress, Agronomy\&Leaf Integrity and Phytopathology\&Genetics" 9-13 ${ }^{\text {th }}$ October 2016. Berlin/Germany

Cabadan, H., S. Ekren and E. Ilker. 2014. Effects of different fertilizer application on the yield of Izmir tobacco. 25th International Scientific Experts Congress on Agriculture and Food Industry. Poster Presentation. Vol. 2, pp.249-252. 2527th September 2014 Cesme-Izmir/Turkey.

Camas, N., H. Karaali, A. K. Ayan. 2007. Investigaiton on some quality and expertise observations of Bafra tobaccos. Turkey VII. Field Crops Congress, 25-27 ${ }^{\text {th }}$ June 2007. pp.421-426. Erzurum (in Turkish).

Camas, N., H., Karaali, O. Calıskan, D. Kurt. 2009a. Determination the yield and yield components of "Basma" tobacco cultivars and accession under Gumushacikoy conditions. Turkey VIII. Field Crops Congress, 19-22 ${ }^{\text {th }}$ October 2009. pp.247-251. Hatay (in Turkish).

Camas, N., O. Caliskan, M. S. Odabas, A. K. Ayan. 2009b. The effects of organic originated fertilizer doses on yield and quality of Esendal tobacco cultivar. Turkey VIII. Field Crops Congress, 19-22 ${ }^{\text {th }}$ October 2009. pp.251-254. Hatay (in Turkish).

Ekren, S. 2007. Investigation on the factors affecting the yield and quality of the Aegean Region tobaccos. Ege University Garaduate School of Natural and Applied Science. PhD Thesis. Bornova-Izmir (in Turkish).
Ekren, S., C. Er, A. E. Celen and E. Ilker. 2015. The effects of different planting methods on tobacco quality and yield on Izmir type tobacco. 26th International Scientific Experts Congress on Agriculture and Food Industry. Oral Presentation. pp.259-264. 27-30th September 2015 Sarejova/Bosna.

Er, C. 1994. Tobacco Drug and Spices Plants. Ankara University Agriculture Faculty. Number: 1359. Ankara (in Turkish).

Fisher, L.R., G. F. Peedin and W.D. Smith. 2002. Factors effecting early field growth of flue-cured tobacco transplants produced in the float system. Tobacco Science, 45:35-43.

Gencer, S. 2001. Tobacco Cultivars in Turkey. Aegean Agricultural Research Institute Publications. Number: 101. Menemen / Izmir (in Turkish)

Gumus Guler, S. 2008. Economic analysis of oriental tobacco in Turkey. Bulgarian Journal of Agricultural Science, 14 (No 5), 470-475.

Harputlu, U., S. Ekren and E. Ilker. 2014. Assesment of different fertilizer doses on yield Izmir tobacco variety under irrigated and non-irrigated conditions. 25th International Scientific Experts Congress on Agriculture and Food Industry. Poster Presentation. Vol. 2, pp.289-292. 25-27th September 2014 Cesme-Izmir/Turkey.

Hou-Long, J., 1. Na-Jia, X. An-ding, Y. Chao, W. Hong-Feng, C. Hai-Tao, s. Pei-Xiang, D. Wei. 2014. Development of closed-type transplant production system and discussion of its application mode for flue-cure tobacco. Australian Journal of Crop Science. AJCS 8(11): 1566-1570. ISSN:1835-2707.

Kabranavo, R., Z. Arsov, Z. Dimov and M. Spirkovska. 2014. Impact of float tray technology on quality of oriental tobacco seedling. 49th Croatian\&9th International symposium on Agriculture. P.362-366. Dubrovnik/Croatia.

Kınay, A.2014. Yield and quality properties in some oriental tobacco (Nicotiana tabacum L.) hybrids. Gaziosmanpasa University, graduate School of Natural and Applied Science, Department of Field Crops. Tokat. PhD Thesis. (in Turkish).

Kille, T. 1970. Early preparations for this years' tobacco crop. Rhod. Tob. J. 22:25-27.

Koseoglu, K.E., S. Ekren and A. E. Celen. 2014. The effects of different fertilizer application on yield of Izmir-Ozbas type of tobacco. 25th International Scientific Experts Congress on Agriculture and Food Industry. Poster Presentation. Vol. 2, pp.309-312. 25-27th September 2014 Cesme-Izmir/Turkey.

Kucukozden, R., A. Peksuslu and S. Sekin. 2002. Yield and quality characters of Izmir type tobacco cultivars in Izmir region of Turkey. The Second Balkan Scientific Conference Quality and Efficieny of the Tobacco Production, Treatment and Processing. p:72-80. Plovdiv/Bulgaria.

Kurt, D. and A.K., Ayan. 2014. Effect of the different organic fertilizer sources and doses on yield in organic tobacco (Nicotiana tabacum L.) production. Journal of Agricultural Faculty. 1300-2910. E-ISSN: 2147-8848. 31(2) 7-14

Liu G. S., X. Y. Xi and x. D. Shi. 2003. Studies on basical growth rules of flue-cured tobacco seedlings in the floating system. Acta Agrice Boreali-sinica. 18(3):36-40.

Jin, X., B. W. Tiian and F.L. Chen. 2014. Comparative study on intensive three-dimensional breeding and floating seedling raising of flue-cured tobacco. J. Henan agric. Sci. 43(5):6265.

Miner, G.S. 1978. The effects of seedling age and transplanting date on yield and quality of flue-cured tobacco and on harvest extension. Tob. Sci. 22:118-121.

Otan, H., R. Apti. 1989. Tobacco. Aegean Agricultural Research Institute Publications. Number: 83. Menemen / Izmir (in Turkish). 
Pearce, B., g. Palmer, W. Nesmith, L. Townsend. 2005. Guide management of tobacco float systems, Cooperative Extension Service-University of Kentucky-Clooege of Agriculture. ID-132; pp.8.

Peksuslu, A., C. O. Sabanc1, R. Kucukozden and S. Sekin. 2002. Genotype $\mathrm{x}$ environment interactions and heritabilities of some important agronomic traits in tobacco. The Second Balkan Scientific Conference Quality and Efficieny of the Tobacco Production, Treatment and Processing. p:80-85. Plovdiv/Bulgaria

Reddy, P.R.S. and C.H. Sreeramanurthy. 1993. Yield and quality of few tobaccos as of affected by nitrogen. proceeding of national sym. Dec. 1992. Potas and Phosphate Inst. of Canada. India Programme Sector.

Sekin, S. 1986. Tobacco quality and its challengies. Turkey Tobacco and Future Symposium. Tekel 366 YTITM/AEKKM 5. Tokat/Turkey (in Turkish).

Shyu, C., D. C. Lai and E. Y. Chang. 1975. Estimates of heritability for some important characters in various tobacco crosses. Coresta 3-4:83.

Smith, W.D., L.R. Fisher and J. F. Spears. 2003. Transplant production in the float system, in flue-cured tobacco information, North Carolina Cooperative Extension Service. Raleigh; p.21.

Steel,R.G.D., J.A.Torrie and D.A. Dickey. 1997. Principles and Procedures of Statistics. A.Biometrical Approach $3^{\text {rd }}$ Edi. Mc Graw Hill Book. INC. NY.
Suben, M. 1976, Quality control at tobacco. Tekel General Directorate Publications. Istanbul (in Turkish).

Uz, E. 1997. The effects of different transplanting dates and curing in polytene covered tunnel on yield and quality in two tobacco cultivars of Izmir type. Ege University, Garaduate School of Natural and Applied Science. PhD Thesis. Bornova-Izmir (in Turkish).

Uzunoski M. 1989. Proizvodstvo na tutun (Production of tobacco), Stopanski vesnik-Skopje, Zemjodelski fakultet Skopje, 447.

Tso, T.C. 1990. Production Physiology and Biochemistry of Tobacco Plant. Ideals Inc.

Turi, I., D. Hamel, H. Mesi, R. Sanz, V. Radulovi. 2004. Phase out of methyl bromide in production of tobacco seedlings in Croatia. Tütün/Tobacco. Vol:54, No:11-12, 252-256. ISSN: 0494-3244.

Yazan, G., R. Apti, R. Usturali, T. Dizdaroglu and H. Otan. 1993. Curing in polytene covered tunnel of Aegean Region tobaccos. Anadolu. J. Of AARI 1 (1993). 73-97. MARA. Aegean Agricultural Research Institute Menemen/Izmir. (in Turkish).

Zhu, X.X. and Z. J. Sun. 2007. Effects of seedling quality on agronomic trait after transplanting. J. Anhui Agri. Sci. 35(4):1061-1062. 